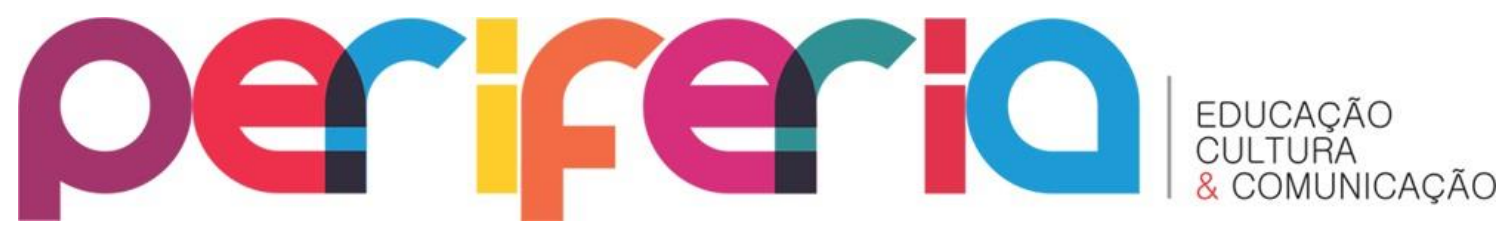

\title{
IDENTIDADE DA ESCOLA DO CAMPO: concepção marxista
}

\author{
Vivianne Costa Sousa ${ }^{1}$ \\ Elen de Fátima Lago Barros Costa ${ }^{2}$ \\ Rayssa Lívia da Silva Reis ${ }^{3}$
}

\section{Resumo}

A educação voltada para a classe trabalhadora do campo tem um histórico de exclusão em políticas educacionais no Brasil. Nesse sentido, a identidade da escola do campo é resultado da luta dos movimentos sociais do campo por garantia do direito à educação protagonizada pelos sujeitos do campo. Este paper discute a identidade da escola do campo. Trata-se de uma revisão de literatura que tem objetivo de colaborar para reflexões acerca da valorização da identidade da escola do campo, com base no materialismo histórico dialético. Conclui-se que a valorização da identidade da escola do campo contribui com a luta de resistência dos povos do campo, especialmente num momento político desfavorável aos direitos sociais historicamente conquistados. Além disso, as reflexões suscitadas contribuem para o entendimento do objeto em profundidade, servindo de base para pesquisas futuras.

\footnotetext{
${ }^{1}$ Mestranda em Educação Profissional e Tecnologia pelo Instituto Federal do Maranhão (IFMA). Graduada em Biologia pela Universidade Estadual do Maranhão (UEMA). Professora da Secretaria Municipal de Educação de São Luiz. Pesquisadora do Grupo de Estudos e Pesquisa Trabalho, Política e Educação Escolar. ORCID: https://orcid.org/0000-0003-0637-3011. E-mail: viviannecosta@acad.ifma.edu.br

2 Doutora em Educação pela Universidade Federal de São Carlos (UFSCar). Mestre em Educação pela Universidade Federal do Maranhão (UFMA), graduada em Pedagogia pela Universidade CEUMA (1993). Graduada em Artes Práticas pela Universidade Federal do Maranhão (UFMA). Professora do PROFEPT/Programa de Pós-graduação em Educação Profissional e Tecnológica. Professora Magistério Superior do Instituto Federal de Educação, Ciência e Tecnologia do Maranhão/IFMA. Líder do Grupo de Pesquisa Estado, Trabalho e Educação. Pesquisadora do Grupo de Estudos e Pesquisas em Educação do Campo/GEPEC/UFSCAR. Pesquisadora do Grupo História, Sociedade e Educação no Brasil - HISTEDBR/UNICAMP - GT Maranhão. Pesquisadora do Grupo de Estudos e Pesquisa Trabalho, Política e Educação Escolar/UFSar. ORCID: https://orcid.org/0000-0001-9790-7669. E-mail: elen@ifma.edu.br

3 Possui graduação em Ciências Sociais pela Universidade Estadual do Maranhão (UEMA), Especialização em Psicologia da Educação pela Universidade Estadual do Maranhão (2016) e Mestranda do Programa de Pós-Graduação em Educação Profissional e Tecnológica pelo Instituto Federal de Educação, Ciência e Tecnologia do Maranhão-IFMA (2019). ORCID: https://orcid.org/0000-0002-4633-4634. E-mail: rayssareis@acad.ifma.edu.br
} 


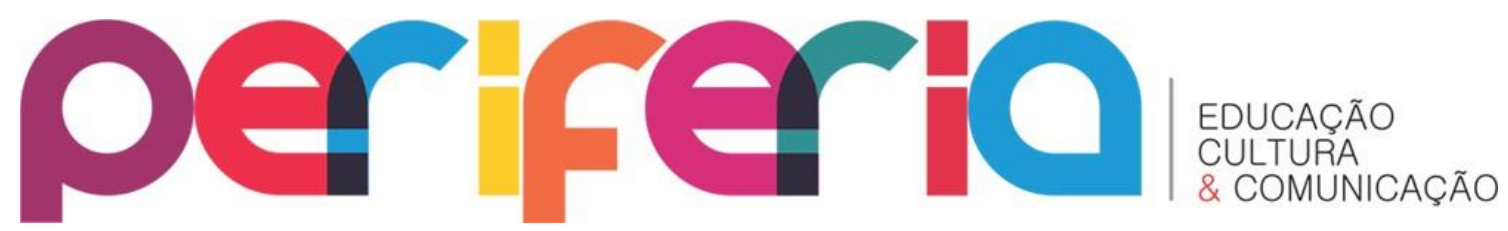

ISSN:1984-9540

DOI: $10.12957 /$ periferia.2021.55982

Palavras-chave: Identidade; Escola do Campo; Políticas Educacionais; Currículo; Pedagogia da Alternância.

\title{
RURAL SCHOOLS IDENTITY: marxist conception
}

\begin{abstract}
The education focused on the working class in the countryside has a history of exclusion in educational policies in Brazil. In this sense, the identity of the rural school is a result of the struggle of the rural social movements to guarantee the right to education led by the people of the countryside. This paper aims to discuss the identity of the rural school. This is a literature review that aims to collaborate for reflections about the valuing of the identity of the rural school, based on historical-dialectical materialism. It is concluded that the valuing of the identity of the rural school contributes to the struggle of resistance of rural people, especially in a unfavorable political moment to the historically conquered social rights. In addition, the reflections raised contribute to the understanding of the object, serving as a basis for future researches.
\end{abstract}

Keywords: Identity; Rural School; Educational Policies; Curriculum; Pedagogy of Alternation.

\section{IDENTIDADE DE LA “ESCUELA DEL CAMPO”: concepción marxista}

\section{Resumen}

La educación dirigida hacia la clase trabajadora del campo tiene un historial de exclusion en políticas educativas en Brasil. En ese sentido, la identidad de la "escuela del campo" es resultado de la lucha de los movimientos sociales por garantizar el derecho a la educación, protagonizada por sus sujetos. Este paper analiza la identidad de la "escuela del campo". Se trata de una revisón de literatura que tiene por objetivo colaborar para reflexiones sobre la valorización de la identidad de la "escuela del campo", a partir del materialismo histórico dialéctico. Se concluye que la valorización de la identidad de la "escuela del campo" contribuye a la lucha de resistencia de 


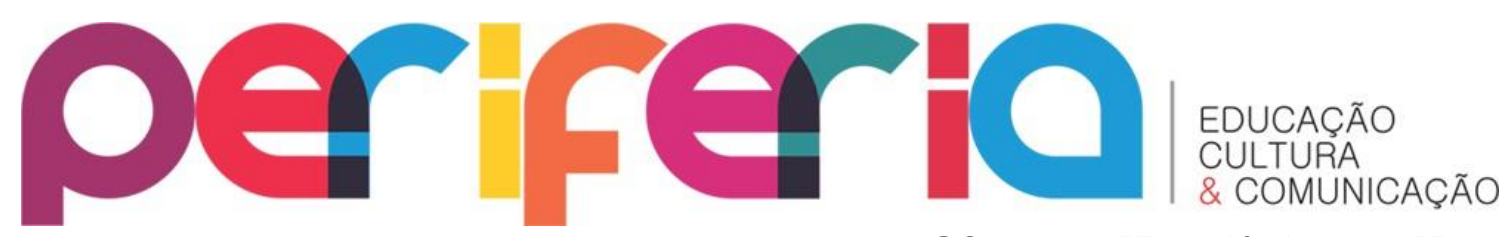

ISSN:1984-9540

DOI: $10.12957 /$ periferia.2021.55982 estos pubelos, especialmente en un momento politico desfavorable a los derechos sociales, históricamente conquistados. Además, las reflexiones alzadas contribuyen para el entendimiento del objeto en profundidad, sirviendo como base para futuras investigaciones.

Palabras clave: Identidad; "Escuela del campo"; Políticas educativas; currículum; Pedagogía de la alternancia.

\section{INTRODUÇÃO}

As populações do campo $^{4}$, por muito tempo estiveram às margens das políticas educacionais no Brasil. Somente a partir da Constituição de 1934, a educação rural foi incluída na legislação brasileira (FILHO; SILVA, 2018). No entanto, a abordagem dada pela maioria dos textos constitucionais trazia um tratamento periférico à educação escolar do campo, numa perspectiva residual e condizente com interesses de grupos hegemônicos na sociedade (BRASIL, 2001). A educação ofertada às classes populares do campo era vinculada a um modelo de educação urbana. Uma tentativa de compensar o atraso causado pela histórica exclusão, porém sem considerar as necessidades desses povos e sem a sua efetiva participação (BICALHO, 2017).

Em contrapartida, no final da década de 90 , movimentos sociais do campo ${ }^{5}$ se mobilizaram por garantia de direitos, articulando a luta pelo direito à terra com as lutas por uma educação do campo protagonizada pelos trabalhadores rurais (MOLINA; FREITAS, 2011). Inicialmente, a luta foi por políticas públicas que garantissem o acesso à educação como direito de todos, como preconiza a Constituição de 1988 (BRASIL, 1988). Esta luta é um dos traços

\footnotetext{
${ }^{4}$ Através do Decreto 7.352/2010, as populações do campo são definidas como: "os agricultores familiares, os extrativistas, os pescadores artesanais, os ribeirinhos, os assentados e acampados da reforma agrária, os trabalhadores assalariados rurais, os quilombolas, os caiçaras, os povos da floresta, os caboclos e outros que produzam suas condições materiais de existência a partir do trabalho no meio rural." (BRASIL, 2010).

5 “Movimentos dos Trabalhadores Rurais Sem Terra (MST); Comissão Pastoral da Terra (CPT); Federação dos Trabalhadores na Agricultura (FETAG); Movimento dos Pequenos Agricultores (MPA); Movimento dos Atingidos por Barragens (MAB); Quilombolas; Caiçaras; Ribeirinhos; Pescadores; Movimentos Indígenas, Via Campesina, entre outros.” (BICALHO, 2017, p. 210).
} 


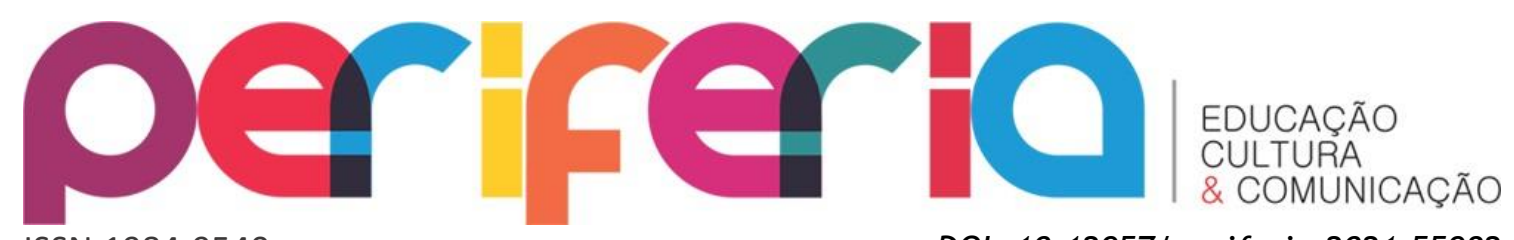

ISSN:1984-9540

DOI: $10.12957 /$ periferia.2021.55982

fundamentais na formação da identidade da educação do campo (CALDART, 2011) e abriu caminho para a conquista de políticas públicas que reconheceram e legitimaram as condições necessárias para que a universalidade do direito à educação se exerça, respeitando as especificidades dos sujeitos do campo (MOLINA; FREITAS, 2011).

É necessário contextualizar essa luta cujas origens estão na resistência às condições de desumanização de vida e trabalho no campo, gerada pela lógica de produção capitalista (CALDART, 2011). Resistência esta que contrapõe lógicas de produção marcadas por projetos distintos, como bem distingue Roseli Caldart (2009): o projeto capitalista do agronegócio (lógica do trabalho produtivo para reprodução do capital) e o projeto da agricultura camponesa (lógica do trabalho para reprodução da vida). Neste confronto de interesses antagônicos, o desafio dos movimentos sociais, que lutam pela reforma agrária e por políticas públicas relacionadas a direitos sociais básicos, é o de construir uma identidade coletiva de classe (RIBEIRO, 2013).

Assim, neste contexto de dupla exclusão, da terra para o trabalho e das políticas educacionais, se inserem os sujeitos da educação do campo: a classe trabalhadora do campo. Sujeitos que, apesar de diferentes, tem uma identidade em comum: um povo que historicamente tem sido vítima de opressão e discriminação econômica, política e cultural (CALDART, 2011).

Cabe ressaltar que o conceito de identidade utilizado situa-se na perspectiva classista do materialismo histórico-dialético. Evidentemente, atentando que os processos de produção e a classe trabalhadora em si passaram por grandes mudanças, especialmente no último século. Contudo, "a classe trabalhadora hoje incorpora a totalidade daqueles/as que vendem a sua força de trabalho em troca de salário incluindo o proletariado rural $^{6}$, que vende a sua força de trabalho para o capital” (ANTUNES, 2018, p. 91).

6 Inclui-se como trabalhadores rurais, os assalariados temporários e permanentes, arrendatários, meeiros, produtores integrados às agroindústrias e produtores familiares que possuem alguns meios de produção, porém “o seu trabalho está submetido indiretamente ao capital; formalmente preserva sua autonomia e aparenta trabalhar para si mesmo, mas na realidade depende do capital financeiro dos bancos que the fazem empréstimos, do capital comercial e do capital industrial" (VENDRAMINI, 2000, p. 24). 


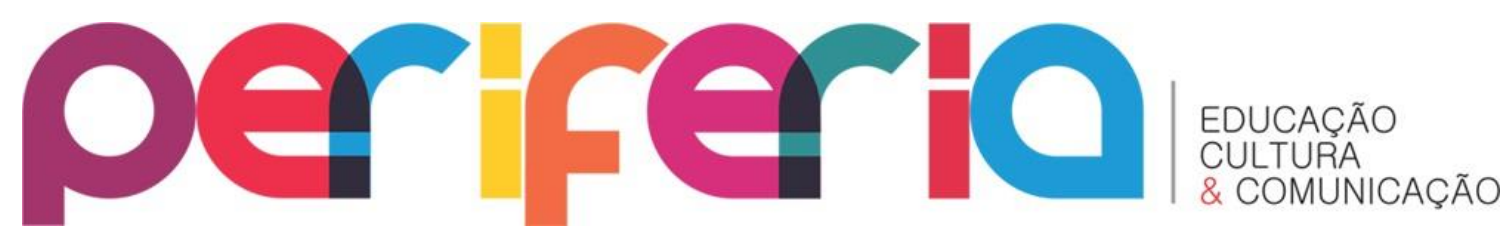

ISSN:1984-9540

DOI: 10.12957/ periferia.2021.55982

Nesta perspectiva,

A Educação do Campo assume sua particularidade, que é o vínculo com sujeitos sociais concretos, e com um recorte específico de classe, mas sem deixar de considerar a dimensão da universalidade: antes (durante e depois) de tudo ela é educação, formação de seres humanos. Ou seja, a Educação do Campo faz o diálogo com a teoria pedagógica desde a realidade particular dos camponeses, mas preocupada com a educação do conjunto da população trabalhadora do campo e, mais amplamente, com a formação humana (CALDART, 2004 p. 3, grifo nosso).

Assim, este artigo discute a identidade da escola do campo com o objetivo de colaborar com reflexões acerca da valorização da identidade da escola do campo, com base no materialismo histórico dialético. Trata-se de um recorte do projeto de pesquisa do Programa de Pós-Graduação em Educação Profissional e Tecnológica - Mestrado Profissional em Rede - PROFEPT.

Esta discussão justifica-se porque apesar dos avanços nas políticas educacionais conquistados pela luta dos movimentos sociais (MOLINA; FREITAS, 2011), as condições de ensino no campo continuam precarizadas. Reflexo disto são os altos índices de evasão escolar no campo, que são mais elevados em todas as etapas do ensino, conforme o Relatório de Desenvolvimento 2012 do Programa das Nações Unidas para o Desenvolvimento - PNUD (BRASIL, 2012). Especialmente no que se refere à educação da classe trabalhadora, a evasão e a consequente baixa escolaridade estão relacionadas à elevação dos índices de pobreza, sujeitando as pessoas a condições de trabalho degradantes (ALMEIDA; LOPES, 2013).

Além disso, esta discussão é relevante nesta fase do capitalismo neoliberal, que no atual cenário político brasileiro se materializa em ações como, a tentativa de despolitização da questão agrária, a criminalização da luta pela terra, a desinstitucionalização da reforma agrária, o uso abusivo de produtos agroquímicos e a violência no campo, impactam diretamente os povos do campo (RODRIGUES, 2020). 


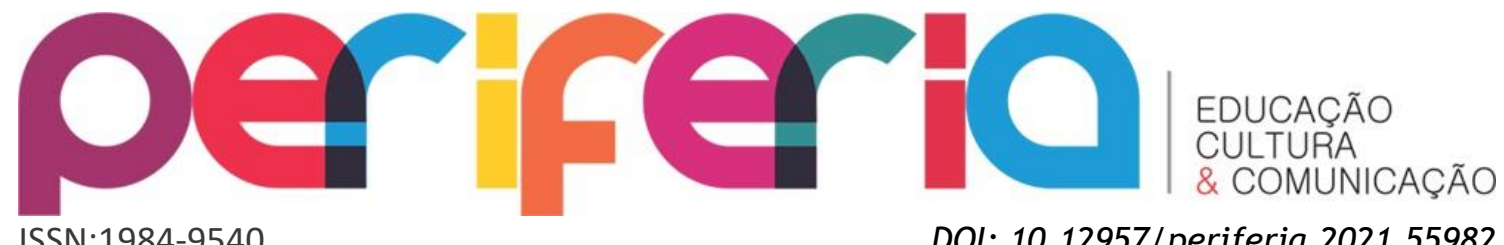

Cabe ressaltar ainda, que o ano de 2019 apresentou a maior quantidade de conflitos no campo no Brasil desde 2010, conforme relatório "Conflitos no campo: Brasil 2019” da Comissão Pastoral da Terra (Tabela 1).

Tabela 1- Total de conflitos no campo no Brasil (2010-2020)

\begin{tabular}{|c|c|c|c|c|c|c|c|c|c|c|}
\hline & 2010 & 2011 & 2012 & 2013 & 2014 & 2015 & 2016 & 2017 & 2018 & 2019 \\
\hline \multicolumn{11}{|c|}{ Conflitos por Terra } \\
\hline $\mathrm{N}^{0}$ de Ocorréncias (1) & 638 & 805 & 816 & 763 & 793 & 771 & 1.079 & 989 & 964 & 1.206 \\
\hline Ocupações/Retomadas & 180 & 200 & 238 & 230 & 205 & 200 & 194 & 169 & 143 & 43 \\
\hline Acampamentos & 35 & 30 & 13 & 14 & 20 & 27 & 22 & 10 & 17 & 5 \\
\hline Total (2) & 853 & 1.035 & 1.067 & 1.007 & 1.018 & 998 & 1.295 & 1.168 & 1.124 & 1.254 \\
\hline Assassinatos & 30 & 29 & 34 & 29 & 36 & 47 & 58 & 70 & 25 & 28 \\
\hline Pessoas Envolvidas & 351.935 & 458.675 & 460.565 & 435.075 & 600.240 & 603.290 & 686.735 & 530.900 & 590.400 & 578.968 \\
\hline Hectares & 13.312 .343 & 14.410 .626 & 13.181 .570 & 6.228 .667 & 8.134.241 & 21.387 .160 & 23.697 .019 & 37.019 .114 & 39.425 .494 & 53.313 .244 \\
\hline \multicolumn{11}{|c|}{ Conflitos Trabalhistas } \\
\hline Trabalho Escravo & 204 & 230 & 168 & 141 & 131 & 80 & 68 & 66 & 86 & 89 \\
\hline Assassinatos & 1 & & & 1 & & & & & & \\
\hline Pessoas Envolvidas & 4.163 & 3.929 & 2.952 & 1.716 & 2.493 & 1.760 & 751 & 530 & 1.465 & 880 \\
\hline Superexploração & 38 & 30 & 14 & 13 & 10 & 4 & 1 & & 3 & 1 \\
\hline Assassinatos & 1 & & & 2 & & 1 & 1 & & 2 & 3 \\
\hline Pessoas Envolvidas & 1.643 & 466 & 73 & 142 & 294 & 102 & 2 & & 12 & 3 \\
\hline Total Conf. Trab. (4) & 242 & 260 & 182 & 154 & 141 & 84 & 69 & 66 & 89 & 90 \\
\hline \multicolumn{11}{|c|}{ Conflitos pela Água } \\
\hline $\mathrm{N}^{0}$ de Conflitos & 87 & 68 & 79 & 93 & 127 & 135 & 172 & 197 & 276 & 489 \\
\hline Assassinatos & 2 & & 2 & 2 & & 2 & 2 & 1 & 1 & 1 \\
\hline Pessoas Envolvidas & 197.210 & 137.855 & 158.920 & 134.835 & 214.075 & 211.685 & 222.355 & 177.090 & 368.465 & 279.172 \\
\hline \multicolumn{11}{|c|}{ Outros } \\
\hline $\mathrm{N}^{0}$ de Conflitos & 4 & & 36 & 12 & & & & & & \\
\hline Assassinatos & & & & & & & & & & \\
\hline Pessoas Envolvidas & 4.450 & & 26.005 & 1.350 & & & & & & \\
\hline \multicolumn{11}{|c|}{ Total dos Conflitos no Campo Brasil } \\
\hline $\mathrm{N}^{0}$ de Conflitos & 1.186 & 1.363 & 1.364 & 1.266 & 1.286 & 1.217 & 1.536 & 1.431 & 1.489 & 1.833 \\
\hline Assassinatos & 34 & 29 & 36 & 34 & 36 & 50 & 61 & 71 & 28 & 32 \\
\hline Pessoas Envolvidas & 559.401 & 600.925 & 648.515 & 573.118 & 817.102 & 816.837 & 909.843 & 708.520 & 960.342 & 859.023 \\
\hline Hectares & 13.312 .343 & 14.410 .626 & 13.181 .570 & 6.228 .667 & 8.134 .241 & 21.387 .160 & 23.697 .019 & 37.019 .114 & 39.425 .494 & 53.313 .244 \\
\hline
\end{tabular}

Fonte: Comissão Pastoral da Terra (2020).

Neste contexto, ressalta-se a importância de se discutir sobre a valorização da identidade da escola do campo para uma formação transformadora como forma de resistência, o que abrange a discussão acerca do currículo e pedagogia da alternância como alternativa educativa que tem uma ligação de origem com a educação do campo. Surgem, na medida em que os povos do campo "se reconhecem sujeitos de conhecimentos, de valores, culturas, sujeitos de processo de humanização/emancipação. Sujeitos pedagógicos, produzindo outras pedagogias." (ARROYO, 2017, p. 25).

\footnotetext{
7 Definidos como "ações de resistência e enfrentamento que acontecem em diferentes contextos sociais no âmbito rural, envolvendo a luta pela terra, água, direitos e pelos meios de trabalho ou produção. Estes conflitos acontecem entre classes sociais, entre os trabalhadores ou por causa da ausência ou má gestão de políticas públicas". (CPT, 2020).
} 


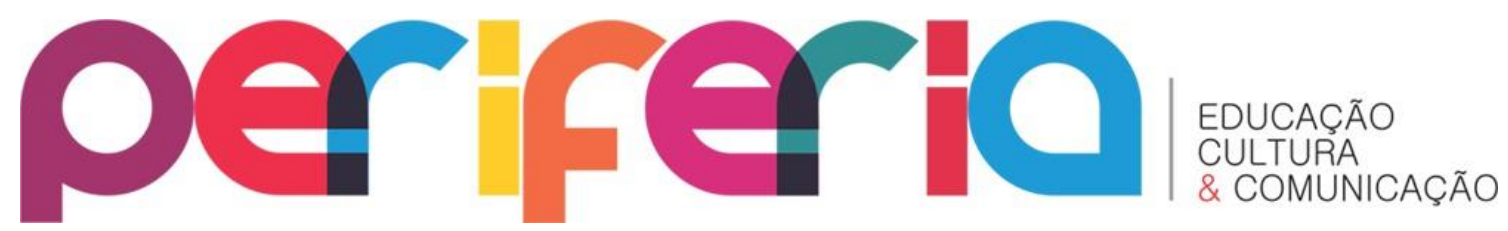

ISSN:1984-9540

DOI: $10.12957 /$ periferia. 2021.55982

Diante disto, a discussão inicia-se com considerações acerca da identidade na perspectiva marxista. Em seguida, aborda-se a construção histórica da educação do campo e a luta dos seus sujeitos por políticas públicas educacionais, o que favorece o entendimento sobre a identidade da escola do campo. Por fim, propõe-se reflexões acerca do currículo e o uso de metodologias adequadas ao campo, como a pedagogia da alternância para a valorização da identidade da escola do campo.

\title{
IDENTIDADE E CLASSE TRABALHADORA DO CAMPO
}

\begin{abstract}
Milhões de famílias existindo sob as condições econômicas que separam o seu modo de vida, os seus interesses e a sua cultura do modo de vida, dos interesses e da cultura das demais classes, contrapondo-se a elas como inimigas, formam uma classe. Mas na medida que existe um vínculo apenas local entre os parceleiros, na medida em que $a$ identidade dos seus interesses não gera nenhum fator comum, nenhuma união nacional $e$ nenhuma organização política eles não constituem classe nenhuma (MARX, 2011, p. 142, grifo nosso).
\end{abstract}

Este excerto da obra "18 Brumário de Luís Bonaparte" de Marx, traduz com maestria a concepção de identidade relacionada à classe social. Nesta perspectiva classista do materialismo histórico-dialético, pretende-se discutir identidade. 0 autor traz um conceito de classe social a partir do campesinato francês, em que relaciona vários aspectos (modo de vida, interesses e cultura) e o complementa associando-o com identidade coletiva.

Neste sentido, segundo Campos e Cassin (2018), Marx coloca a luta e a contraposição à outra classe como fator determinante (não único) para a formação de uma classe social. Além disso, na obra intitulada "Classes sociais em Marx e no marxismo: uma aproximação", os autores enumeram outros critérios para constituição das classes sociais, como "a classe como produto histórico, a constituição da classe na contraposição à classe oposta, a propriedade (ou não) dos meios de produção e a função na organização social da produção." (CAMPOS; CASSIN, 2018, p. 134). 


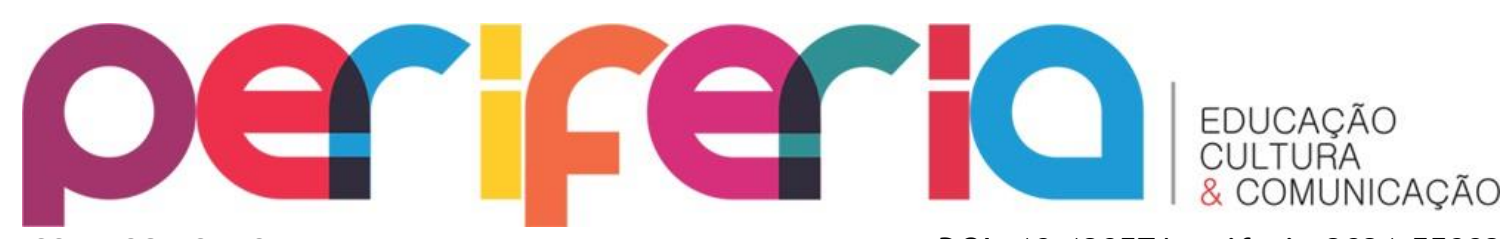

ISSN:1984-9540

DOI: $10.12957 /$ periferia. 2021.55982

Assim, relacionando estes aspectos, e, evidentemente considerando as transformações econômicas e sociais ocorridas no campo, situa-se a abordagem proposta de identidade da classe trabalhadora do campo. Contudo, as identidades modernas que forneceram sólidas localizações como indivíduos sociais, estão sendo descentradas, deslocadas ou fragmentadas pela mudança estrutural ocorridas nas sociedades modernas no final do século XX. Assim, o conceito pós-moderno de identidade está fragmentando as identidades culturais em classe, gênero, sexualidade, etnia, raça e nacionalidade (HALL, 2020).

$\mathrm{Na}$ perspectiva do pós-modernismo ${ }^{8}$, movimentos sociais pautados na identidade, geralmente demandam por igualdade social. Estes "novos movimentos sociais" tem pautado sua luta em torno da identidade, um importante fator de mobilização política e concentram-se na afirmação da identidade cultural de um determinado grupo oprimido ou marginalizado, bem como na análise de sua opressão específica e está fortemente marcada pela diferença (WOODYWARD, 2014, p.34). Esta demanda por igualdade social é necessária. A afirmação da identidade e a enunciação da diferença traduzem o desejo dos diferentes grupos sociais, assimetricamente situados, de garantir o acesso privilegiado aos bens sociais. "A identidade e a diferença estão, pois, em estreita conexão com as relações de poder." (SILVA, 2014, p. 81).

Contudo, especialmente se esta demanda por reconhecimento é pautada na diferença, desloca a luta do coletivo para o individual, mascarando outras contradições. A ação política através da identidade é exatamente o que prende as pessoas ao Estado, o que assegura sua contínua sujeição (HAIDER, 2019). Nesta direção está a crítica marxista: identidade não pode ficar só nas diferenças, na busca de representatividade ou empoderamento individuais, como tem ocorrido em muitos movimentos identitários. Precisa ir além disso, dentro de uma perspectiva classista, visando a transformação das relações sociais de forma mais ampla.

\footnotetext{
8 O conceito de pós-modernismo usado é pautado em Fredric Jameson (1997) que traz ao pósmodernismo uma concepção histórica de lógica cultural do capitalismo avançado (ou tardio), portanto sujeito a mudanças e ação política.
} 


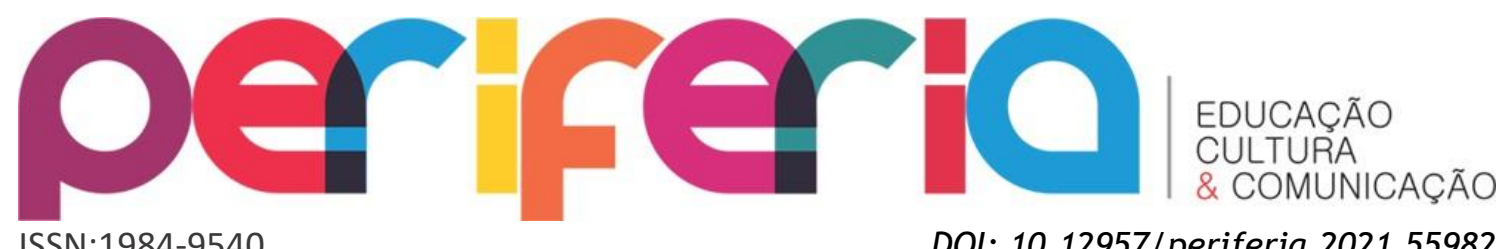

ISSN:1984-9540

DOI: $10.12957 /$ periferia.2021.55982

Nesta perspectiva, a identidade da classe trabalhadora do campo começa a ser formada à medida que os camponeses se organizaram politicamente em defesa de seus interesses coletivos, em oposição aos interesses hegemônicos dos grandes proprietários de terra. Isto pode ser observado na história da luta dos povos do campo por terra e outros direitos. Trata-se, portanto, da formação de uma identidade de resistência às condições de vida e trabalho no campo, à expropriação da terra e à forma de produção agrícola para o mercado. Somando-se a isto, a marginalização dos povos do campo às políticas educacionais também os levou a lutarem por um projeto de educação que os considerassem como sujeitos de direitos (CALDART, 2011).

Nesse sentido,

\begin{abstract}
A negação de direitos aos povos do campo, historicamente recorrente no Brasil, foi o principal elemento mobilizador das lutas empreendidas pelos movimentos sociais e sindicais do campo, que lutavam por terra. Em meados da década de 1990, aliaram-se para construir o Movimento por uma Educação do Campo, com a compreensão de que o modelo da educação rural não atendia ao projeto de fortalecimento do modo de vida camponês. Havia projetos em disputa seja para desencadear a luta por terra, seja para garantir educação para as populações assentadas. A crítica se fazia por outra base pedagógica que considerasse o modo de vida, de produção e reprodução que resguardasse os modos de ser e estar em condição de existência camponesa (ESMERALDO; MOLINA; ANTUNES-ROCHA, 2017, p. 573).
\end{abstract}

Dessa forma, e, considerando a totalidade dos fenômenos sociais, entendida na relação entre os aspectos econômicos e políticos, "a identidade é fruto de uma história, que só pode ser alcançada caso mergulhemos nas relações sociais concretas" (ALMEIDA, 2019).

\title{
IDENTIDADE NAS POLÍTICAS EDUCACIONAIS
}

A educação na sociedade capitalista visa manter o sistema e, reproduzir a lógica de produção dominante que subjuga o trabalhador ao capital. Desse caráter da estrutura social capitalista decorre o papel da educação escolar 


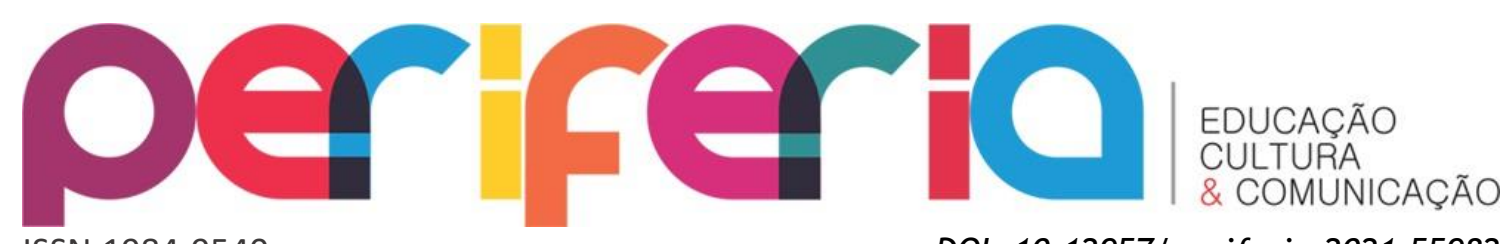

ISSN:1984-9540

DOI: $10.12957 /$ periferia.2021.55982

(SAVIANI, 2013). Esta lógica tem contornos mais acentuados na educação ofertada para a classe trabalhadora do campo no Brasil, por seu histórico de luta pela terra de trabalho e por políticas educacionais, os quais foram historicamente excluídos.

Nesse sentido, no que se refere à educação e políticas educacionais para o campo, é importante mencionar que a oferta de educação para a população rural foi contemplada a primeira vez somente na Constituição de 1934. Neste período de intenso êxodo rural gerado pelo processo de industrialização, houve o surgimento do ruralismo pedagógico: uma proposta de educação para o meio rural tinha o propósito de manter os filhos dos trabalhadores rurais no campo. No entanto, voltada aos interesses das classes dominantes, esta formação essencialmente profissional contribuiu para o processo de industrialização do campo. Prado (1995, p. 6) situa o ruralismo pedagógico "na defesa de uma escola adaptada e sempre referida aos interesses e necessidades hegemônicas".

Neste sentido, nas décadas de 40 e 50, a Revolução Verde trouxe mudanças significativas no modo de produção agrícola, que fomentou políticas desfavoráveis à classe trabalhadora do campo. Além da concentração de terras, o crédito para grandes empreendimentos, a mecanização das práticas agropecuárias, se configurava também o cenário de precariedade física, administrativa e pedagógica das escolas rurais (MOLINA; ANTUNES-ROCHA, 2014). Nesta mesma lógica hegemônica, foi criada a Lei Orgânica do Ensino Agrícola/ Decreto-Lei 9613/46 que "tinha como objetivo principal a preparação profissional para os trabalhadores da agricultura." (BRASIL, 2001).

Assim, as constituições a partir 1934 abordaram a educação rural de forma compensatória e excludente, com marcado caráter de classe; a Constituição de 1988, entretanto, ao garantir a educação como direito para todos, abriu precedentes legais para a luta por políticas públicas educacionais que considerassem as necessidades e participação dos sujeitos do campo.

Nesta direção, depois de reformas educacionais, a Lei de Diretrizes e Bases da Educação/LDB 9394/96 (BRASIL, 1996), foi a primeira a trazer avanços consideráveis quanto às especificidades da educação do campo. 0 capítulo 28 aborda a oferta de educação às populações rurais do ponto de vista da 


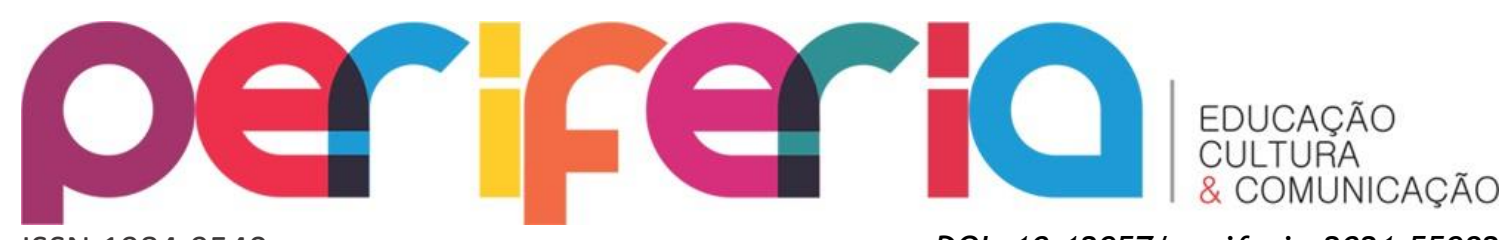

ISSN:1984-9540

DOI: $10.12957 /$ periferia. 2021.55982

adequação e não mais da adaptação à educação urbana, como era comumente abordada.

Após a Constituição de 1988 e LDB/96, por meio da mobilização dos movimentos sociais do campo, foram criadas políticas públicas em prol da educação do campo considerando a identidade de seus sujeitos. Dessa forma, "o percurso da educação do campo foi desenhando a dimensão da política pública como um dos seus pilares principais, na tensão permanente de que esta dimensão não 'engolisse' a memória e a identidade dos seus sujeitos originários." (CALDART, 2009, p. 52).

Neste contexto, no final da década de 1990, de acordo com Soares (2018) diversos atores sociais se uniram ao Movimento Sem Terra (MST), como o Fundo das Nações Unidas para a Infância (Unicef), o Fundo das Nações Unidas para a Ciência e Cultura (Unesco) e a Conferência Nacional dos Bispos do Brasil (CNBB), na luta por educação do campo. Assim,

\begin{abstract}
Tendo sua origem no processo de luta dos movimentos sociais para resistir à expropriação de terras, a Educação do Campo vincula-se à construção de um modelo de desenvolvimento rural que priorize os diversos sujeitos sociais do campo, isto é, que se contraponha ao modelo de desenvolvimento hegemônico que sempre privilegiou os interesses dos grandes proprietários de terra no Brasil, e também se vincula a um projeto maior de educação da classe trabalhadora, cujas bases se alicerçam na necessidade da construção de um outro projeto de sociedade e de Nação (MOLINA; FREITAS, 2011, p. 19).
\end{abstract}

Como resultado desta mobilização foram conquistados instrumentos legais e políticas públicas de grande importância para os sujeitos do campo e que, porque pensados a partir de suas demandas e com sua participação, colaboraram para a construção da identidade da escola do campo.

Pode-se citar por exemplo, as Diretrizes Operacionais para Educação Básica das Escolas do Campo, definidas pela Resolução CNE/CEB $n^{\circ} 1 / 02$ (BRASIL, 2002), que foi uma adequação dos Parâmetros Curriculares Nacionais (PCN) para o campo. Este foi o primeiro dispositivo legal que tratou sobre a organização das escolas do campo, considerando a identidade de seus sujeitos. As Diretrizes Operacionais em seu bojo reconhecem o "modo próprio de vida 


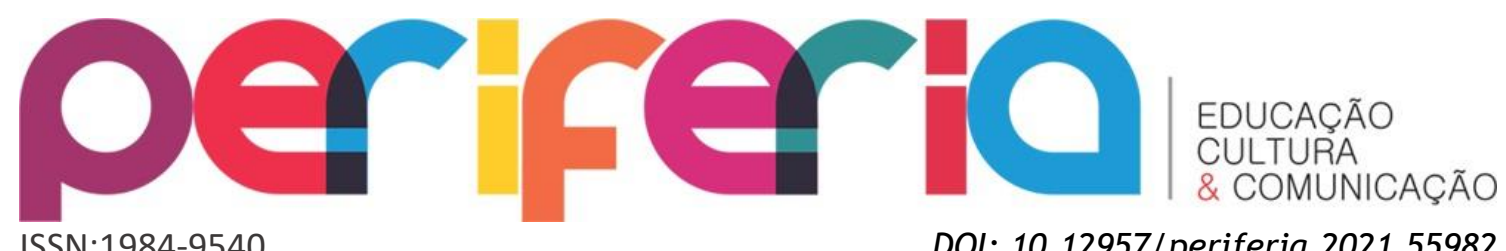

ISSN:1984-9540

DOI: $10.12957 /$ periferia.2021.55982 social e o de utilização do espaço do campo como fundamentais, em sua diversidade, para a constituição da identidade da população rural e de sua inserção cidadã na definição dos rumos da sociedade brasileira” (BRASIL, 2002, p. 1).

Nesta direção, também se tem o Decreto $n^{\circ}$ 7.352/2010 (BRASIL, 2010) que dispõe sobre a Política Nacional de Educação do Campo e sobre o Programa Nacional de Educação na Reforma Agrária (PRONERA). Este decreto teve grande relevância, pois regulamentou o PRONERA como política pública doze anos depois de sua criação. O PRONERA surgiu em 1998 a partir da "demanda dos movimentos sociais e sindicais por uma educação que valorizasse a identidade dos povos do campo" e financia cursos em diversos níveis, inclusive educação profissional. (RODRIGUES, 2020, p. 101).

Estas políticas públicas foram conquistadas a fim de garantir o acesso e permanência das populações do campo na escola, como direito de todos. Contudo, buscando metodologias alternativas que considerem a especificidade dos sujeitos e a identidade da escola do campo, contudo sem desconsiderar a importância dos conhecimentos socialmente construídos pela humanidade. Ou seja,

\begin{abstract}
garantindo-se universalidade com especificidade, e implementando-se algumas características metodológicas que permitiriam alcançar a igualdade: entrada coletiva com turmas e seleções específicas, pedagogia da alternância e participação de diferentes e desiguais sujeitos históricos/atores sociais. (RODRIGUES, 2020, p. 126).
\end{abstract}

Neste sentido, a elaboração de políticas públicas de formação identitária dos povos do campo perpassa a dualidade educacional brasileira. Esta relação dual entre educação com o trabalho intensifica-se na educação profissional do campo, porque a escola agrícola historicamente destinou-se à qualificação para o trabalho rural, como "preparação de mão de obra para os processos de modernização e expansão das relações capitalistas na agricultura" (CALDART, 2012, p. 260).

Assim, a educação profissional no campo acompanhou as mudanças nas relações de trabalho no campo, influenciadas pela industrialização trazida com 


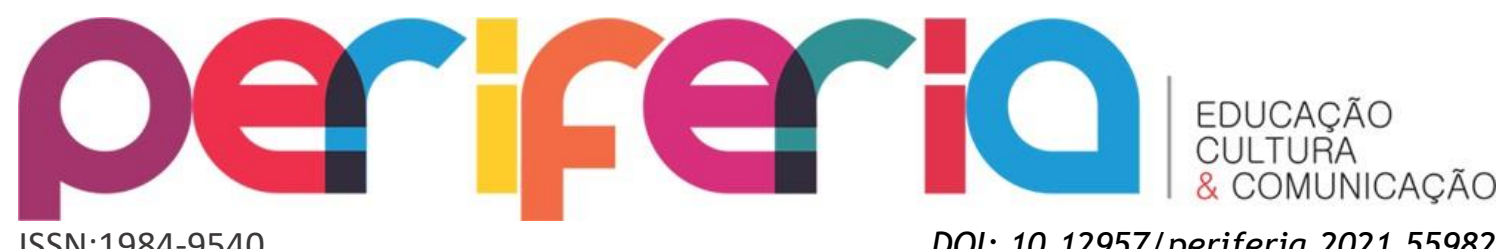

a Revolução Verde e consequentemente a modernização da agricultura para o mercado. A reestruturação capitalista que provoca fragmentação e precarização das relações de trabalho (ANTUNES, 2018), no campo, reforça o agronegócio e influencia o projeto de educação para os trabalhadores rurais. Nesta direção, Gritti (2008, p. 128) reforça ao afirmar que “o técnico agrícola é produzido no bojo do processo de complexificação/fragmentação e decorrente necessidade de controlar e direcionar o modelo de produção para a agricultura".

Dessa forma, a educação profissional do campo sofre investidas do capital manifestadas no campo através do agronegócio e materializadas através de programas como Programa Nacional de Acesso ao Ensino Técnico e Emprego no Campo (PRONATEC CAMPO) ${ }^{9}$, com cursos voltados para a agricultura de mercado, a fim de formar uma reserva de profissionais para o capital. Trata-se de mais uma ferramenta da estratégia de construção da hegemonia da agricultura capitalista que se pretende seja dominante. É a preparação de mãode-obra para o trabalho mais desqualificado que o agronegócio demanda. (FONEC, 2012, p.18).

Em contrapartida, a educação profissional pensada a partir dos movimentos sociais do campo, por meio de programas como o PRONERA, por exemplo, promovem acesso à profissionalização do campo, pautada em princípios como “o trabalho como princípio pedagógico, o encontro com a técnica e a ciência como produtoras de tecnologias sociais; a cultura como princípio pedagógico e a relação campo cidade de modo crítico, ao pensar a totalidade da formação da classe trabalhadora brasileira" (PEREIRA, 2012, p. 289).

Portanto, mesmo com os avanços das políticas educacionais, a educação para os povos do campo precisa vincular-se a outros direitos sociais, como acesso à terra e ao trabalho. Dessa forma, o processo de construção e afirmação da identidade camponesa precisa ser analisado a partir de sua tríade

\footnotetext{
${ }^{9}$ O PRONATEC CAMPO é uma política pública demandada pelo Ministério do Desenvolvimento Agrário (MDA). Trata-se de educação profissional direcionadas para sujeitos que vivem no campo (BRASIL, 2018).
} 


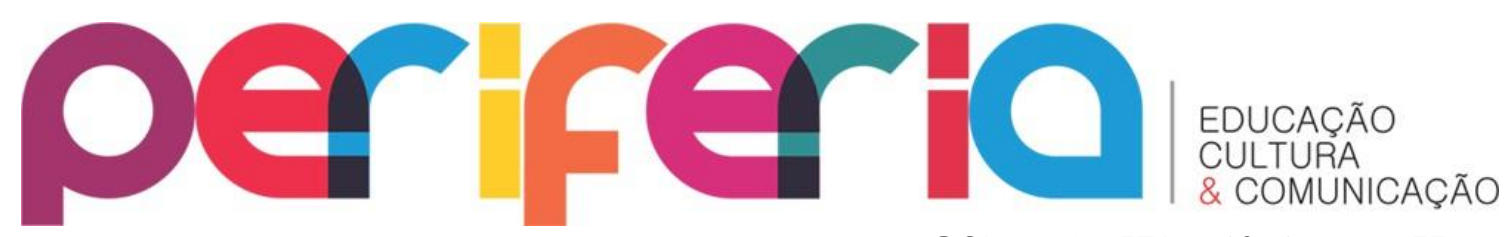

ISSN:1984-9540

DOI: $10.12957 /$ periferia.2021.55982

estruturante: campo/políticas públicas/educação. As relações e contradições que ocorre nesses três âmbitos são fundamentais para compreender as razões históricas segundo as quais foram se materializando as lutas dos camponeses brasileiros pelo direito à terra e à educação de maneira absolutamente indissociável (FERNANDES; MOLINA, 2017, p. 541).

\section{IDENTIDADE DA ESCOLA DO CAMPO}

A identidade da escola do campo é definida pela sua vinculação
às questões inerentes à sua realidade, ancorando-se na
temporalidade e saberes próprios dos estudantes, na memória
coletiva que sinaliza futuros, na rede de ciência e tecnologia
disponível na sociedade e nos movimentos sociais em defesa de
projetos que associem as soluções exigidas por essas questões
à qualidade social da vida coletiva no país. (BRASIL, 2002, p. 1)

Esta resolução que traz as Diretrizes Operacionais para Educação Básica das Escolas do Campo foi resultado da luta dos movimentos sociais do campo por políticas públicas e representa um marco no que se refere à inserção da identidade do campo em um dispositivo legal. Contudo esta definição se consubstancia considerando-se as condições materiais concretas.

Nesse sentido, o Decreto 7352/2010 (BRASIL, 2010), que instituiu o PRONERA como política pública, traz o tema com mais profundidade em seu artigo $2^{\circ}$, inciso $\mathrm{VI}$,

[...] valorização da identidade da escola do campo por meio de projetos pedagógicos com conteúdos curriculares $e$ metodologias adequadas às reais necessidades dos alunos do campo, bem como flexibilidade na organização escolar, incluindo adequação do calendário escolar às fases do ciclo agrícola e às condições climáticas (BRASIL, 2010, grifo nosso).

Este inciso traz a valorização da identidade da escola do campo como um dos princípios da educação do campo. Além disso, orienta expressamente que a forma desse reconhecimento deve ser por meio de projetos pedagógicos com conteúdos curriculares e metodologias adequadas às reais necessidades dos alunos do campo. 


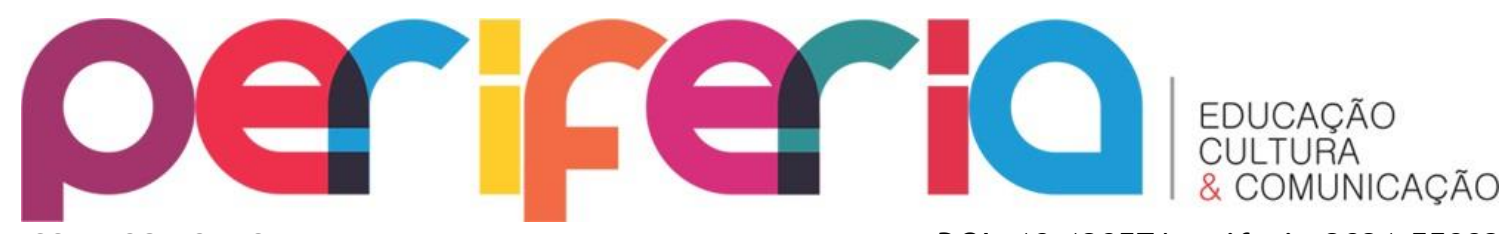

ISSN:1984-9540

DOI: $10.12957 /$ periferia.2021.55982

Partindo dessa proposição, considera-se central a discussão acerca do currículo e das metodologias de ensino voltadas para o fortalecimento da identidade das escolas do campo.

\title{
Currículo
}

"A disputa do currículo não é uma questão exclusivamente escolar; antes, trata-se de uma disputa pelo projeto de sociedade travado mais amplamente na luta de classes" (RAMOS, 2016, p. 224). Nesta direção, é essencial pensar e ressignificar o currículo, porque "não há currículo ingênuo, ele sempre implica em uma opção e esta opção poderá ou não ser favorável ao processo de humanização (BRASIL, 2008).

Sob este viés, um breve histórico sobre a educação do campo mostra que a legislação tem sido omissa na regulamentação de um currículo que atenda às necessidades dos sujeitos do campo. A luta por uma educação que reflita, e ao mesmo tempo, reproduza a identidade camponesa, perpassa pela reflexão acerca do currículo, pelo questionamento de que sujeitos se pretende formar.

Logo,

\begin{abstract}
Esse movimento histórico de redefinição da concepção de currículo para a Educação do Campo representa a problematização das propostas de educação implantadas nas escolas do meio rural, as quais não favoreceram o questionamento das identidades e/ou subjetividades presentes no currículo escolar, das relações sociais de produção efetivadas no campo, bem como das relações de poder que fazem parte da seleção e legitimação do conhecimento curricular. (MATOS; ROCHA, 2020, p.19).
\end{abstract}

Nesta perspectiva, o currículo ao assumir a posição crítica, pretende ir além das teorias curriculares porque defende uma proposta pedagógica concreta centrada nos interesses da classe trabalhadora, baseada em princípios do materialismo histórico dialético e defende a Pedagogia Histórico-Crítica como uma norteadora de uma concepção de currículo na perspectiva da classe trabalhadora (RAMOS, 2016). 


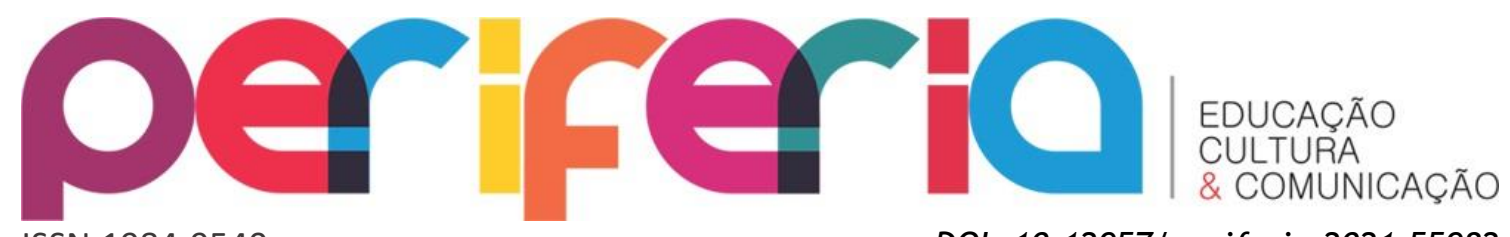

ISSN:1984-9540

DOI: $10.12957 /$ periferia.2021.55982

Dessa forma, pensar o currículo numa perspectiva mais ampla, de humanização dos sujeitos, é refletir a partir de sua relação com o trabalho, visando uma formação integral dos trabalhadores do campo e, mais especificamente, o fortalecimento de sua identidade como classe trabalhadora. Assim,

O currículo da escola do campo deve ter como central a formação humana, priorizar a relação do trabalho na terra como forma de fortalecer a identidade campesina, independente da atividade profissional que o cidadão opte em exercer. 0 currículo precisa incorporar, no processo educativo escolar, a relação educação e cultura, e garantir a estudantes conhecimento das diversas formas de manifestações culturais, mas principalmente a cultura campesina. (SANTOS, 2018, p. 195).

Nessa perspectiva, as questões de identidade permeiam as teorias do currículo, que se diferenciam, inclusive, pela ênfase que dão a seleção de saberes, como conhecimento, cultura e sociedade. Além da questão do conhecimento, o currículo também é uma questão de identidade, pois estão situadas num campo epistemológico social. "As teorias críticas e pós-críticas estão preocupadas com as conexões entre saber, identidade e poder." (SILVA, 2010, p. 15).

No entanto,

o que define a seleção de conteúdos e métodos no currículo na perspectiva da classe trabalhadora são os interesses dos dominados, posto que a escola visaria a garantir à classe 0 acesso ao conhecimento, bem como sua assimilação efetiva para que, ao compreender a realidade, possa produzir formas de transformá-la. (RAMOS, 2016, p. 229).

\section{Pedagogia da Alternância}

A Pedagogia da Alternância foi fortalecida na educação do campo no Brasil, como uma ação afirmativa, principalmente por causa da ausência de programas educacionais oficiais que considerassem a realidade do campo, da falta de condições estruturais que permitissem aos jovens uma formação 


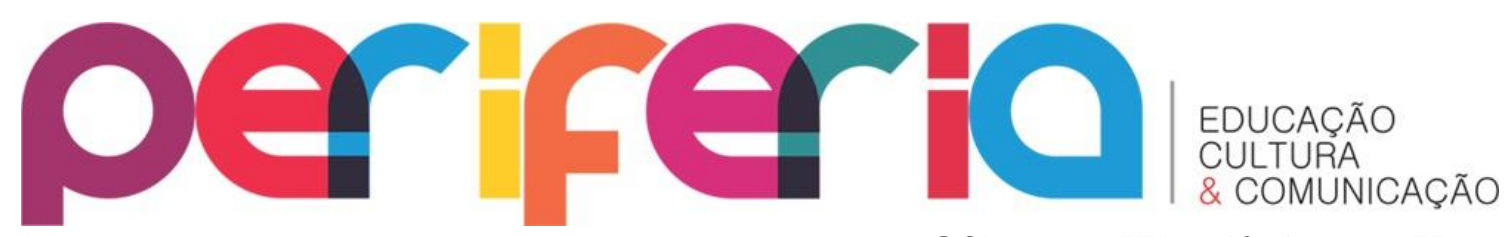

ISSN:1984-9540

DOI: $10.12957 /$ periferia.2021.55982

baseada no diálogo e na interação de diferentes realidades ao longo do seu processo formativo (FROSSARD, 2017).

É importante ressaltar que a Pedagogia da Alternância teve sua origem na experiência francesa das Maisons Familiales Rurales (Casas Familiares Rurais), em 1935. Ideia que surgiu da junção da igreja com os sindicatos rurais, quando pensaram em ressignificar a escola dos jovens da zona rural. No Brasil, a alternância completou 50 anos de atuação no ano passado, a partir de sua implantação no Espírito Santo, em 1969, com as Escolas Famílias Agrícolas (EFAs). Depois, se expandiu por vários estados, inclusive com outras denominações, como Casas Familiares Rurais (CFRs). Atualmente, o termo Centros Familiares de Formação por Alternância (CEFFAs) ${ }^{10}$ é usado para designar as experiências de alternância no Brasil (NOSELLA, 2014).

Assim, esta metodologia de ensino caracteriza-se por alternar momentos, lugares e atividades formativas. 0 tempo escola é o momento de estudo realizado nas instituições de ensino, enquanto o tempo comunidade ocorre junto às famílias e comunidades. Sobre as atividades desenvolvidas, Caldart (2004) afirma que,

[...] o tempo escola, onde os educandos têm aulas teóricas e práticas, participam de inúmeros aprendizados, se auto organizam para realizar tarefas que garantam o funcionamento da escola, avaliam o processo e participa do planejamento das atividades, vivenciam e aprofundam valores; [...] o tempo comunidade, que é o momento onde os educandos realizam atividades de pesquisa da sua realidade, de registro desta experiência, de práticas que permitem a troca de conhecimento nos vários aspectos. Este tempo precisa ser assumido e acompanhado pela comunidade. (CALDART, 2004, p. 105).

Contudo, a Pedagogia da Alternância não se resume apenas a alternar diferentes espaços e tempos educacionais. Este é um dos pilares meios que,

10 CEFFA é um nome genérico, até então de caráter político, formulado no Brasil, em 2001, que busca articular e unir Escolas Famílias Agrícolas, Casas Familiares Rurais e Escolas Comunitárias Rurais, para lutarem juntamente, no âmbito nacional, pelo reconhecimento da Pedagogia da Alternância e pelo financiamento público, em marcos legais que assegurem, todavia, os seus princípios constitutivos. Conceito contido no posfácio de atualização do livro de Nosella, pelos autores Begnami e Burghgrave. (NOSELLA, 2014). 


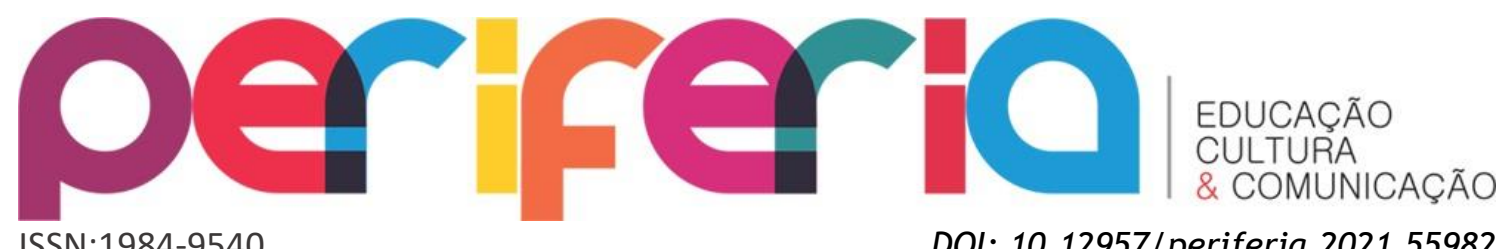

ISSN:1984-9540

DOI: $10.12957 /$ periferia.2021.55982 junto com a associação com as famílias/comunidade, configuram-se como estratégias metodológicas para se alcançar uma formação integral e profissional com base na agroecologia que são os pilares fins desta proposta. Frossard (2019) afirma que a agroecologia como finalidade deu às escolas de alternância no Brasil não somente um teor de educação ambiental, mas também de movimento social e de resistência à expansão da agricultura empresarial e a toda demanda tecnológica de grande impacto ambiental, disseminada desde a Revolução Verde.

Nesta perspectiva, a Pedagogia da Alternância vincula-se à educação do campo por buscar uma formação que tenha o trabalho como princípio educativo para uma educação integral e emancipatória. Sobre isto, Marlene Ribeiro (2008) afirma que esta metodologia tem o trabalho como princípio de uma formação humanista que relaciona de forma dialética ensino formal e trabalho produtivo, "mas sem perder de vista nem a contradição capital-trabalho, que se apoia sobre a separação entre cidade e campo, nem o movimento provocado pela luta de classes, cujos interesses das classes em conflito atravessam as experiências dos sujeitos coletivos” (RIBEIRO, 2008, p. 30).

\section{CONSIDERAÇÕES FINAIS}

A construção da identidade da escola do campo está vinculada ao processo histórico de luta dos povos do campo por acesso à terra para o trabalho e à educação. Esta identidade não deve está centrada na diferença, mas numa perspectiva classista de resistência da classe trabalhadora que vive no campo.

Neste sentido, compreender os processos que resultaram nas políticas públicas educacionais identitárias no campo brasileiro e, consequentemente a sua relação com a realidade do campo, é fundamental para ressignificar o currículo e estimular metodologias de ensino que fortaleçam a identidade da escola do campo e, por consequência, favoreçam a permanência escolar.

O capitalismo neoliberal no Brasil, reflete um momento político desfavorável aos direitos sociais conquistados historicamente pelos trabalhadores. Ações como o desmonte do Pronera e a paralisação da política 


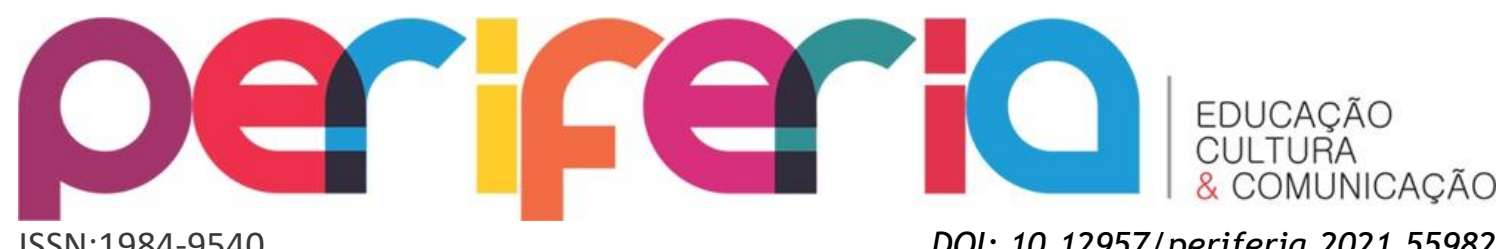

da Reforma Agrária, criminalização dos movimentos sociais do campo, incentivo à violência com o armamento no campo, institucionalização da grilagem de terras, regulação das terras indígenas, incêndios "descontrolados" na região amazônica e liberação indiscriminada de agrotóxicos reforçam o agronegócio e representam um retrocesso para os povos do campo. Nesta perspectiva, a proposta governamental para a educação do campo está centrada na educação como mercadoria, voltada à lógica capitalista no campo, baseada na construção do conhecimento para ser usada como mão de obra para o agronegócio, e não para um processo de humanização e emancipação.

Dessa forma, ressalta-se a importância da educação do campo na contribuição para a transformar as relações sociais de trabalho subordinadas à lógica do capital no campo. Nesta direção, a escola do campo tem muitos desafios para contemplar uma formação que compreenda as relações de produção no campo voltada para uma formação emancipatória. Assim, refletir sobre a educação do campo tendo o fortalecimento da identidade da escola do campo como estratégia de resistência camponesa e identificação com a prática produtiva dos povos no campo é um caminho para essa prática transformadora. Afinal, "o papel da educação escolar será um se ela for posta a serviço do desenvolvimento do capital, portanto, a serviço dos interesses da classe dominante. E será outro, se ela se posicionar a favor dos interesses dos trabalhadores." (SAVIANI, 2013, p. 23).

Por fim, espera-se que as reflexões suscitadas contribuam para o entendimento da identidade da escola do campo, pois considera o objeto em suas múltiplas relações e em seu contexto histórico, para além da aparência buscando desvelar a realidade em sua essência, conforme Marx; e assim, sirvam de base para pesquisas futuras.

\section{REFERÊNCIAS}

ALMEIDA, Ana Roberta; LOPES, Janete Leige. Qual a relação entre escolaridade, trabalho degradante e pobreza: uma análise estatística. In: VIII EPCT - ENCONTRO DE PRODUÇÃO CIENTÍFICA E TECNOLÓGICA, 2013. Campo Mourão, Paraná. 


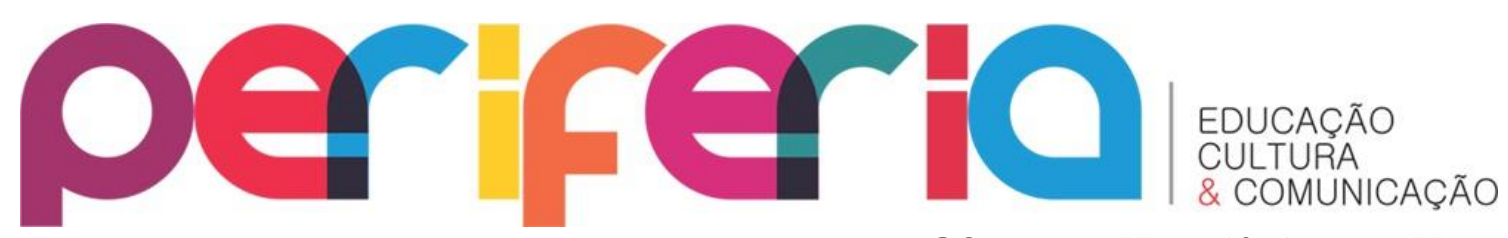

ISSN:1984-9540

DOI: $10.12957 /$ periferia.2021.55982

ALMEIDA, Silvio Luis. Prefácio da Edição Brasileira. In: HAIDER, Asad.

Armadilha da identidade: raça e classe nos dias de hoje. Tradução Leo

Vinicius Liberato. São Paulo: Veneta, 2019. 160 p. 7 - 19.

ANTUNES, Ricardo. O privilégio da servidão: o novo proletariado de serviços na era digital. São Paulo: Boitempo, 2018. 325 p.

ARROYO, Miguel Gonzalez. Outros Sujeitos, Outras Pedagogias. 2. ed.

Petrópolis: RJ. Vozes, 2017.

BICALHO, Ramofly. História da educação do campo no Brasil: o protagonismo dos movimentos sociais. Revista Teias, Rio de Janeiro, v. 18, n. 51, p. 210224, out-dez, 2017. Disponível em: https://www.e-

publicacoes.uerj.br/index.php/revistateias/article/view/24758. Acesso em: 10 ago. 2020.

BRASIL. Constituição Federativa do Brasil de 1988. Disponível em:

http://www.planalto.gov.br/ccivil_03/constituicao/constituicao.htm. Acesso em: 13 de ago. 2020.

BRASIL. Decreto n. 7.352, de 04 de novembro de 2010. Dispõe sobre a política de educação do campo e o Programa Nacional de Educação na Reforma

Agrária - PRONERA. Disponível em:

http://www.planalto.gov.br/ccivil_03/_ato2007-

2010/2010/decreto/d7352.htm\#: : text=Decreto\%20n\%C2\%BA\%207352\&text=DE CRETO\%20N\%C2\%BA\%207.352\%2C\%20DE\%204,que\%20lhe\%20confere\%20o\%20art. Acesso em: 20 jun. 2020.

BRASIL. Lei $n^{0}$ 9.394, de 20 de dezembro de 1996. Estabelece as diretrizes e bases da educação nacional. Disponível em:

http://www.planalto.gov.br/ccivil_03/leis/19394. Acesso em: 20 ago. 2020.

BRASIL. Ministério da Educação. Secretaria da Educação Básica. Indagações sobre currículo. Brasília: MEC/SEB, 2008.

BRASIL. Ministério da Educação. Pronatec. Brasília, 2018. Disponível em: http://portal.mec.gov.br/pronatec. Acesso em: 10 ago. 2020.

BRASIL. Parecer CNE/CEB $n^{\circ} .36 / 2001$. Diretrizes Operacionais para a Educação Básica nas Escolas

do Campo. Brasília: MEC, 2001. Disponível em:

http: / / portal.mec.gov.br/index.php?option=com_docman\&view=download\&al ias=13800-rceb001-02-pdf\&category_slug=agosto-2013-pdf\&ltemid=30192.

Acesso em 10 ago. 2020.

BRASIL. Programa das Nações Unidas para o Desenvolvimento (PNUD). Relatório de Desenvolvimento 2012. Disponível em: 


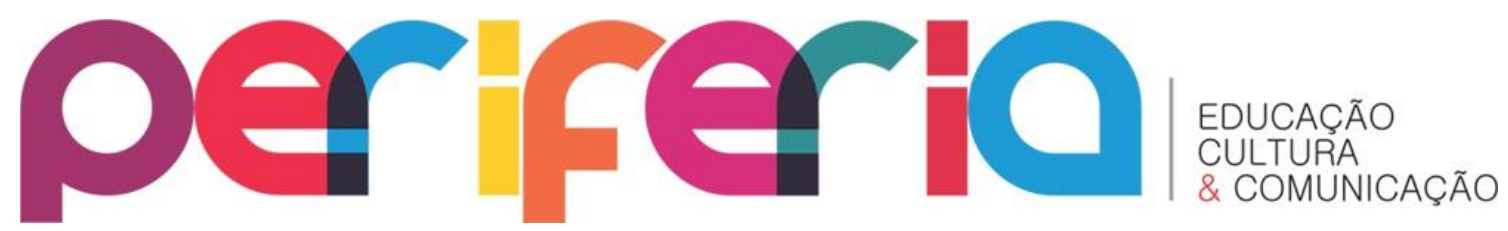

ISSN:1984-9540

DOI: $10.12957 /$ periferia.2021.55982

https://issuu.com/pnudbrasil/docs/pnud_relat_rio_anual_web. Acesso em: 25 out. 2020.

BRASIL. Resolução CNE/CEB n. ${ }^{\circ} 1$, de 3 de abril de 2002. Institui Diretrizes Operacionais para a Educação Básica nas Escolas do Campo. Brasília, 2002, CNE. Disponível em: http://portal.mec.gov.br/escola-de-gestores-daeducacao-basica/323-secretarias-112877938/orgaos-vinculados82187207/13200-resolucao-ceb-2002. Acesso em: 20 jun. 2020.

CALDART, Roseli Salete (org.) et al. Dicionário da Educação do Campo. Rio de Janeiro: EPSJV; São Paulo: Expressão Popular, 2012.

CALDART, Roseli Salete. Educação do campo: notas para uma análise de percurso. Trabalho, Educação e Saúde, Rio de Janeiro, v. 7, n. 1, p. 3564, jun. 2009. Disponível em:

http: / / www.scielo.br/scielo.php?script=sci_arttext\&pid=S198177462009000100 003\&lng=en\&nrm=iso. Acesso em: 11 ago. 2020.

CALDART, Roseli Salete. Pedagogia do Movimento Sem Terra. São Paulo: Expressão Popular, 2004.

CALDART, Roseli Salete. Por uma Educação do Campo: traços de uma identidade em construção. In: ARROYO, Miguel. Gonzalez. CALDART, Roseli Salete, MOLINA, Mônica. Castagna (orgs.). Por uma Educação do Campo. Petrópolis, RJ: Vozes, 2011. p. 148-158.

CAMPOS, Estevan Martins de; CASSIN, Marcos. Classes sociais em Marx e no marxismo, uma aproximação. Impulso, Piracicaba, v. 28, n. 72, p. 129-138, maio-ago., 2018. Disponível em: http://dx.doi.org/10.15600/22369767/impulso.v28n72p129-138. Acesso em: 20 maio 2020.

CPT. Comissão Pastoral da Terra. Conflitos no campo: Brasil/2019. Goiânia: CPT, Nacional, 2020. Disponível em: https://www.cptnacional.org.br/component/jdownloads/?task=download.sen d\&id=14195\&catid=0\&m=0\&ltemid=0. Acesso em: 30 out. 2020.

ESMERALDO, Gema Galgani Silveira Leite; MOLINA, Mônica Castagna; ANTUNES-ROCHA, Maria Isabel. O fortalecimento da identidade camponesa: repercussões do programa nacional de educação na reforma agrária nos estados do Ceará, Minas Gerais e Paraná (1998-2011). Educ. e Soc., Campinas, v. 38, n. 140 , p. 569-585, jul. 2017. Disponível em: http:// www.scielo.br/scielo.php?script=sci_arttext\&pid=S010173302017000300569\&lng=en\&nrm=iso. Acesso em: 19 ago. 2020.

FELICIANO, Carlos Alberto. Espaços rebeldes em tempos de atraso: a tentativa de despolitização da questão agrária no Brasil. In: RODRIGUES, Sônia Silva da (org.). PRONERA: gestão participativa e diversidade de sujeitos da Educação do Campo. Marília: Lutas Anticapital, 2020. p. 7-15. 


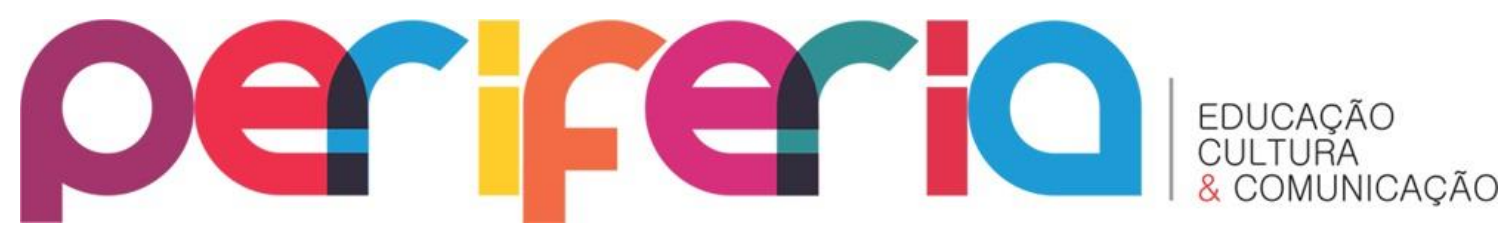

ISSN:1984-9540

DOI: $10.12957 /$ periferia.2021.55982

FERNANDES, Bernardo Mançano; MOLINA, Mônica Castagna. Análises de experiências brasileiras e latino-americanas de educação do campo. Educação e Sociedade, Campinas, v. 38, n. 140, p. 539-544, Jul. 2017. Disponível em: http: / / www.scielo.br/scielo.php?script=sci_arttext\&pid=S01017330201700030 0539\&lng=en\&nrm=iso. Acesso em: 03 maio 2020.

FERNANDES, Bernardo Mançano; TARLAU, Rebecca. Razões para mudar o mundo: a Educação do Campo e a contribuição do Pronera. Educ.

Soc., Campinas, v. 38, n. 140, p. 545-567, jul. 2017. Disponível em: https: / / www.scielo.br/scielo.php?pid=S0101 -

73302017000300545\&script=sci_abstract\&tlng=pt. Acesso em: 28 ago. 2020.

FILHO, I. D. C.; SILVA, C. DA. Reflexões sobre a educação do campo. Revista de Educação Popular, v. 16, n. 3, p. 67-83, 9 jan. 2018. Disponível em: http://www.seer.ufu.br/index.php/reveducpop/article/view/38835. Acesso em: 10 ago. 2020.

FONEC. Fórum Nacional de Educação Do Campo. Notas para análise do momento atual da Educação do Campo. In: Seminário Nacional. 15 a 17 ago. Brasília, 2012, p. 01-28. Disponível em: http://ww.gepec.ufscar.br/textos1/legislacao1/forum-nacional-de-educacaodo-campo-2013-fonec-notas-paraanalise-do-momento-atual-da-educacao-docampo/at_download/filef. Acesso em: 5 ago. 2020.

FROSSARD, Antônio Carlos. Contextualização e questões teóricas acerca da Pedagogia da alternância. Coleção Pedagogia da Alternância - Vol. 1. Nova Friburgo: Editora Fross, 2017. 119 p.

FROSSARD, Antônio Carlos. Pedagogia da Alternância: Derrubando estereótipos e construindo identidades. Um estudo de caso. Nova Friburgo, RJ: Editora Fross, 2019. 179 p.

GRITTI, Silvana Maria. Educação profissional rural: formação técnica. Educação (UFSM), v. 33, n. 1, abr. 2008. Disponível em: https://periodicos.ufsm.br/reveducacao/article/view/23. Acesso em: 20 jul. 2020.

HAIDER, Asad. Armadilha da identidade: raça e classe nos dias de hoje. Tradução Leo Vinicius Liberato. São Paulo: Veneta, 2019. 160 p.

HALL, Stuart. A identidade cultural na pós-modernidade. Tradução Tomaz Tadeu da Silva, Guaracira Lopes Louro. 12. ed. Rio de Janeiro: Lamparina, 2020.

MARX, Karl. O 18 de Brumário de Luís Bonaparte. Tradução Nélio Schneider. São Paulo: Boitempo, 2011. 


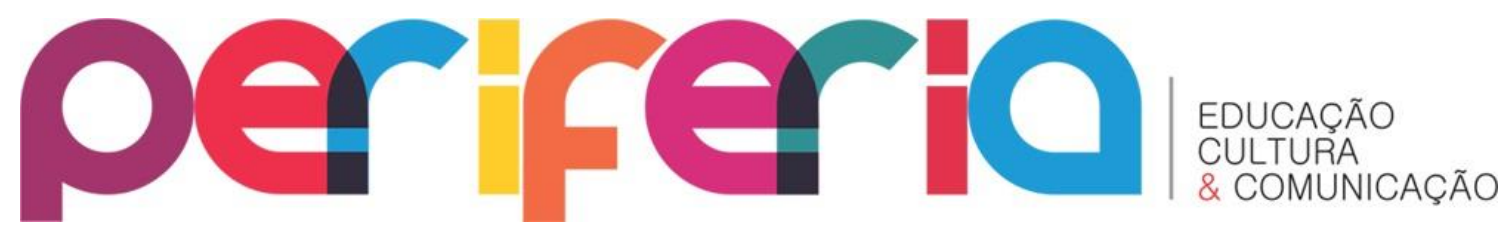

ISSN:1984-9540

DOI: $10.12957 /$ periferia.2021.55982

MATOS, Cleide Carvalho de; ROCHA, Glenylton Odilon Rêgo da. Currículo da Educação do Campo no contexto das legislações nacionais. Revista Brasileira de Educação do Campo, v. 5, p. 1 - 23, jan. 2020. Disponível em: https://sistemas.uft.edu.br/periodicos/index.php/campo/article/view/4582/ 16300. Acesso em: 19 jun. 2020.

MOLINA, Molina Castagna; FREITAS, Helana Célia de Abreu. Avanços e desafios na construção da educação do campo. Em Aberto, Brasília, v. 24, n. 85, p. 1731, 2011. Disponível em:

https: / / seminarionacionallecampo2015.files.wordpress.com/2015/09/avanc3 a7os-e-desafios-na-construc3a7c3a3o-da-educac3a7c3a3o-do-campo.pdf. Acesso em: 15 jul. 2020.

MOLINA, Monica Castagna; ANTUNES-ROCHA, Isabel. Educação do Campo: história, práticas e desafios no âmbito das políticas de formação de educadores - reflexões sobre o Pronera e o Procampo. Reflexão e Ação, Santa Cruz do Sul, v. 22, n. 2, p. 220-253, dez. 2014. Disponível em:

https://online.unisc.br/seer/index.php/reflex/article/view/5252. Acesso em: 19 ago. 2020.

NOSELLA, Paolo. Origens da pedagogia da alternância no Brasil. Vitória: Edufes, 2014. 288 p.

PEREIRA, Isabel Brasil. Educação Profissional. In CALDART, Roseli Salete (org.) et al. Dicionário da Educação do Campo. Rio de Janeiro: EPSJV; São Paulo: Expressão Popular, 2012. p. 289-294.

PRADO, Adonia Antunes. Ruralismo pedagógico no Brasil do Estado Novo. Estudos Sociedade e Agricultura, 4 Jul. 1995. P. 5-27. Disponível em: http://biblioteca.clacso.edu.ar/ar/libros/brasil/cpda/estudos/quatro/adonia 4.htm. Acesso em: 20 jul. 2020.

RAMOS, Marise. O Currículo na Perspectiva de Classe: Desafios e Possibilidades para a Educação Profissional. Rev. Educere et Educare, v. 11, n. 23, jul./dez. 2016. Disponível em: http://e-

revista.unioeste.br/index.php/educereeteducare/article/view/16332. Acesso em: 10 out. 2020.

RIBEIRO, Marlene. Movimento camponês, trabalho e educação: liberdade, autonomia e emancipação princípios/fins da formação humana. 2 ed. São Paulo: Expressão Popular, 2013. 456 p.

RIBEIRO, Marlene. Pedagogia da alternância na educação rural/do campo: projetos em disputa. Educação e Pesquisa, São Paulo, v. 34, n. 1, p. 27-45, jan./abr. 2008. Disponível em:

http://www.scielo.br/scielo.php?script=sci_arttext\&pid=S1517-

97022008000100003\&lng=pt\&nrm=iso. Acesso em: 11 ago. 2020. 


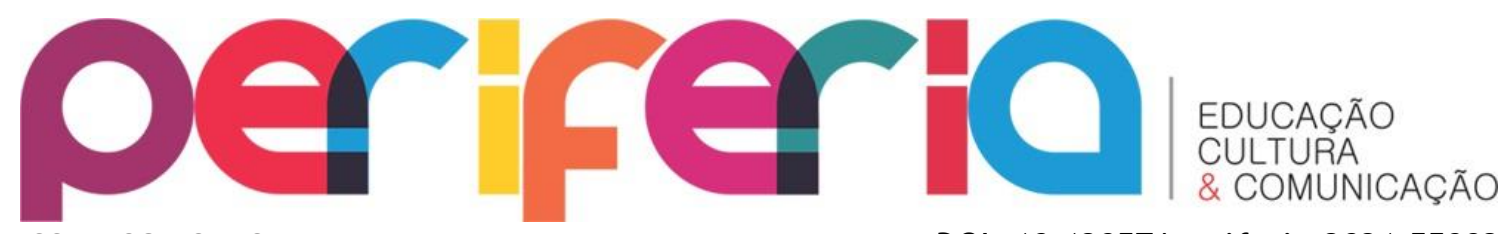

ISSN:1984-9540

DOI: $10.12957 /$ periferia.2021.55982

RODRIGUES, Sônia Silva da (org.). PRONERA: gestão participativa e diversidade de sujeitos da Educação do Campo. Marília: Lutas Anticapital, 2020. 317 p.

SANTOS, Marilene. Educação do Campo no Plano Nacional de Educação: tensões entre a garantia e a negação do direito à educação. Ensaio: aval.pol.públ.Educ., Rio de Janeiro, v. 26, n. 98, p. 185-212, mar. 2018 . Disponível em: https: / /www.scielo.br/scielo.php?pid=S010440362018000100185\&script=sci_arttext. Acesso em: 14 jun. 2020.

SAVIANI, Dermeval. A pedagogia histórico-crítica, as lutas de classe e a educação escolar. Germinal: Marxismo e Educação em Debate, Salvador, v. 5, n. 2, p. 25-46, jan. 2013. Disponível em:

https: / / cienciasmedicasbiologicas.ufba.br/index.php/revistagerminal/article /view/9697/7085. Acesso em: 25 ago. 2020.

SILVA, Tomaz Tadeu da. A produção social da identidade e da diferença. In: SILVA, Tomaz Tadeu da (org.), Identidade e diferença: a perspectiva dos estudos culturais. 15. ed. Petrópolis: Vozes, 2014. p. 73-101.

SILVA, Tomaz Tadeu da. Documentos de Identidade: Uma Introdução às Teorias de Currículo. $3^{\circ}$ Edição. Editora Autêntica. 2010. 156 p.

SOARES, Sávia Bona. Estado e Educação do campo: a influência dos organismos internacionais na elaboração de políticas públicas educacionais para o campo brasileiro. Revista Inter Ação, v. 43, n. 1, p. 240-258, 2018. Disponível em: https://www.revistas.ufg.br/interacao/article/view/46081. Acesso em: 14 ago. 2020.

WOODWARD, Kathryn. Identidade e diferença: Uma introdução teórica e conceitual. In: SILVA, Tomaz Tadeu da (org.), Identidade e diferença: a perspectiva dos estudos culturais. 15. ed. Petrópolis: Vozes, 2014. Disponível em:

https://edisciplinas.usp.br/pluginfile.php/4284077/mod_resource/content/1 /cap\%C3\%ADtulo\%20I\%20-\%20Woodward\%20-\%20IDENTIDADE-E-DIFERENCAUMA-INTRODUCAO-TEORICA-E-CONCEITUAL.pdf. Acesso em: 28 ago. 2020. 